\title{
Social perceptions of floods and flood management in a Mediterranean area (Costa Brava, Spain)
}

\author{
A. Lara $^{1}$, D. Saurí ${ }^{2}$, A. Ribas ${ }^{1}$, and D. Pavón ${ }^{1}$ \\ ${ }^{1}$ Department of Geography, University of Girona, 17071 Girona, Spain \\ ${ }^{2}$ Department of Geography, Autonomous University of Barcelona, 08193 Bellaterra, Spain
}

Received: 17 June 2010 - Revised: 8 September 2010 - Accepted: 9 September 2010 - Published: 6 October 2010

\begin{abstract}
Taking as an example three study cases in the Costa Brava area, this paper examines the social perception of floods through surveys, interviews and Focus Group sessions. Perception is then related to vulnerability, flood management, and citizen's preferences regarding alternatives to curb flood losses in the future. The study concludes that flood awareness and the willingness to take actions regarding this hazard are clearly related to the degree of social involvement with the affairs of the local community. Furthermore, participatory settings such as Focus Group sessions appear to enable a better environment for assessing and implementing flood management options that attempt to modify human activities rather than modify natural processes as has been frequently the case in the past.
\end{abstract}

\section{Introduction}

Floods remain the most common natural disaster worldwide (Llasat et al., 2009). In Europe, in the period 1998-2002, floods accounted for $43 \%$ of all disasters suffered by the continent. Some 100 flood events affected a combined area of one million $\mathrm{km}^{2}$, caused approximately seven hundred dead, half a million displaced, and economic losses of $€ 25$ billion. In terms of deaths, Southern and Eastern Europe took the heaviest toll whereas Central Europe and the United Kingdom registered the highest economic impacts. This uneven geography of flood damages also raises questions about the true nature of economic losses. Thus while it is becoming increasingly clear that economic losses caused by floods follow an upward trend it also appears increasingly certain that mounting losses are more related with social rather than natural factors (Barredo, 2009).

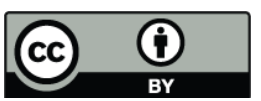

Correspondence to: A. Ribas (anna.ribas@udg.edu)
Recent episodes of flooding occurring on the Mediterranean coast have shown again that the flood hazard ${ }^{1}$ never disappears completely but takes new forms and affects new territories in response to changing socio-territorial conditions. Probably, more than ever, the flood risk is inextricably bound up with human actions and decisions (Renn, 1998), and science appears to be just another actor in this complex and dynamic social and natural environment. No matter how convincingly meteorological, geomorphologic and hydrological analyses insist on the perils of developing flood prone land for urban purposes, the reality is that more and more of these hazardous areas are being transformed into variety of urban uses. In 2002, the European Environment Agency, in its report "Environmental Signals" indicated that in the last twenty years the urban area in Europe had increased by 20\% (EEA, 2002). Most of this growth had taken place in Southern Europe, and, again, a substantial part was located in land potentially affected by floods, droughts, forest fires, and other environmental hazards.

Given this state of affairs, investigations into the human and social sides of the flood hazard are more necessary than ever. One of the first issues to be critically examined is the false sense of security that the technocratic approach to flood management has contributed to generate (Adams, 1995). At the same time, this technological fix has neglected the social and environmental dimensions of flooding (Meyer et al., 2009). The omission of the social and the environmental

\footnotetext{
${ }^{1}$ It is important to clarify the expressions "flood hazard" and "flood risk" (see Llasat et al., 2009). In the context of this paper, "flood risk" means the combination of the probability of a flood event and of the potential adverse consequences for human health, the environment, cultural heritage and economic activity associated with a flood event (Directive on the Assessment and Management of Floods (2007/60/EC). Article 2, no. 2). On its part, "flood hazard" is the likelihood of occurrence of a flood, within a specified period and in a given area (Real Decreto 903/2010, de 9 de julio, de Evaluación y Gestión de Riesgos de Inundación).
}

Published by Copernicus Publications on behalf of the European Geosciences Union. 
component in both hazard analysis and the development and implementation of actions aimed at mitigation can lead to misleading conclusions such as to blame losses on the irrationality of people or, at the opposite site, to blame the ferocity of nature under the disguise of a truly extraordinary event.

Research on human perception of floods has a history of over 50 years, after the pioneering studies of NorthAmerican geographers Gilbert White, Robert Kates and Ian Burton (Kates, 1962; Burton et al., 1993). These studies showed very early that individual flood perception and hence the likelihood of undertaking management measures to curb losses was highly correlated with previous experience of floods and the immediacy of a damaging episode. Another interesting finding was the presence among people affected of the psychological strategy known as "cognitive dissonance"; that is the difficulty in admitting erroneous behaviour and, in parallel, tendency of blaming someone else for losses but never oneself. Furthermore, perception studies have also noted that for the general public, flood management was seen as a public rather than private matter and that protection from floods should be the responsibility of public authorities. This change from the individual to the collective sphere is also reproduced at the different scales of government. Thus local governments argue that flood management, including as a fundamental component the construction and financing of hydraulic infrastructures, should be the responsibility of regional, national or even supranational (i.e. the European Union) governments. The preferences for certain options over others also indicate a common feature of flood perception by individuals and local governments affected by floods: that the costs of flood protection should be spread out to the wider society, for instance, through taxes that pay for hydraulic flood control measures.

Many of the elements embedded in individual flood perception may respond to a historical period in which large segments of human populations and very especially population living in urban areas have severed their ties with nature and tend to perceive natural processes such as floods as something produced by an "uncontrolled nature" to be remediated by technological fixes. This perception has been facilitated by the ever growing role of the state in flood management, capturing more and more flood protection options that in the past used to be performed at the individual or local levels. However, during the recent decades, several factors have contributed to undermine this state of affairs. First, absolute protection from floods has proven impossible or only attainable at infinite costs. Second, social and environmental impacts have cast many doubts on the feasibility of large flood protection works while at the same time environmental concerns about the fate of rivers and streams have raised opposition against these works. Perhaps more fundamentally, the general retreat of the public sphere in part because of increasing financial difficulties together with the consolidation of new forms of governance may be altering institutional and social attitudes to flood management in general. The Water Framework Directive of 2000 and more specifically the Directive on Floods of 2007 send fairly clear signals regarding the increasing commitments to be made by individual citizens in water and flood management (very especially the assumption of economic costs previously borne by the state). Specifically, Sect. 15 says that "The solidarity principle is very important in the context of flood risk management. In the light of it Member States should be encouraged to seek a fair sharing of responsibilities, when measures are jointly decided for the common benefit, as regards flood risk management along water courses." Also, article 10, point 2, states that "member States shall encourage active involvement of interested parties in the production, review and updating of the flood risk management plans referred to in Chapter IV." In turn, these responsibilities passed back to the private sphere were to be compensated in a way by increasing public participation as a means to involve more those potentially affected and reach more sustainable and equitable solutions to the flood problem.

Under these new governance frameworks, if we have to overcome the limitations of the technocratic view in flood management, more multidisciplinary analyses, where the citizen is an active component, are needed (Pearce, 2005). Uncertainty dominates both hazard analysis and adaptation and mitigation strategies. Experts have a high awareness of the hazard, but they may ignore the local conditions in which hazards occur. Therefore, to enrich risk management with the local knowledge of residents may not only increase the chances of better performance of flood protection and alleviation but also involve the citizenry in more active roles (Edelenbos and Klijn, 2006). In this sense, several authors (Lacey and Longman, 1997; Platt, 1999; Plapp, 2001; Brilli and Polic, 2005; Guzzetti et al., 2005) have addressed the role of the social component either as an active or as a passive entity and its influence in hazard management.

From a more practical standpoint there are several cases where people play an active role in disaster management, such as the HEROS program (Home Emergency Response System Organization), in Coquitlam, British Columbia, Canada. This programme engaged leaders and volunteers from the neighbourhoods on specific flood management tasks (inventories of equipment to be used in a disaster, lists of special situations that may affect neighbours, storage of food, water and medical equipment, etc.). Residents receive basic emergency training, which is transformed into a proactive tool when facing a potential disaster. Australia and New Zealand are also examples of involvement by people in the management of disasters (Australia and New Zealand Standards Associations, 1995). However, in flood and water management the Netherlands provide perhaps the best examples of citizen participation and commitment since the thirteenth century. The Dutch Water Boards are organizations based on the principle of volunteerism, and remain responsible for water management and flood protection (Huisman, 1997). For 


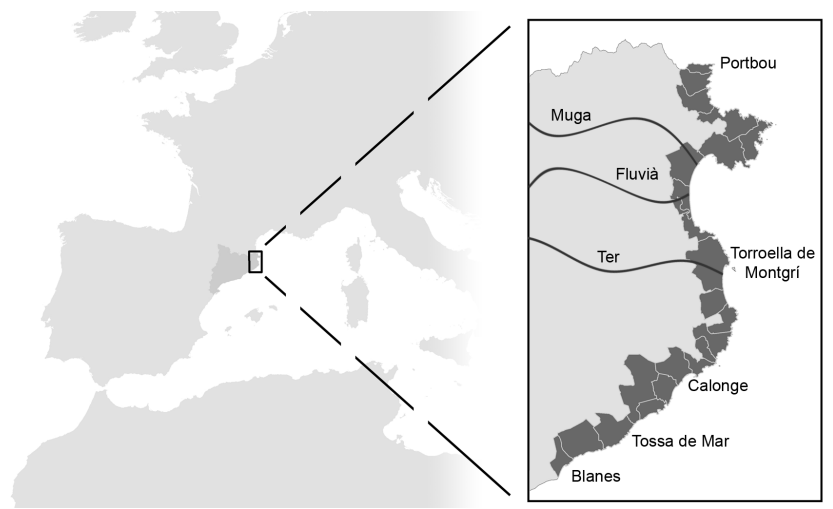

Fig. 1. Situation map of the Costa Brava.

instance, the entire Dutch male population between 18 and 60 years must comply with a responsibility to protect the levees and/or residents from flooding.

Despite all these initiatives, the public is generally left apart when decisions concerning flood management are made (Rubin, 1991). As Pearce (2003, p. 216) further argues "if disaster managers and community planners ignore the local community, then they decrease their providing reasonable chance of disaster-related solutions to problems". For these reasons, the EU Floods Directive (2007/60/EC) recognizes the necessity of public participation in the making of public policy concerning floods. From this perspective, any new strategy of flood management will have to consider the perception of different social agents (citizens, public servants, private interests, NGOs, etc.) and of their likely vulnerability to floods, their assessment of current management practices, and their views and actions on strategies aimed at alleviating the impacts of these phenomena (Olcina, 2007; Calvo and Granell, 2009).

The success of public involvement, however, is not guaranteed by mere calls to participation. Furthermore, the type of participation will likely influence public perception and assessment of floods. One hypothesis worth testing is whether and how perception and assessment of floods change depending on the participative methodology selected. In other words, whether processes of social learning with respect to certain natural phenomena are better facilitated by certain participatory methods and obscured by others. Understanding the fact that the public may learn differently and therefore elaborate different attitudes to floods and flood management according to the participatory setting chosen may be essential for the development of public policies that: (a) involve changes in human behaviour in flood prone areas, (b) engaging citizens in the new processes of governance; (c) make feasible a complete and comprehensive approach to flood risk analysis; (d) ease the development of genuine and effective strategies to mitigate the risk of flooding (e) consolidate the objectives of the EU Floods Directive.

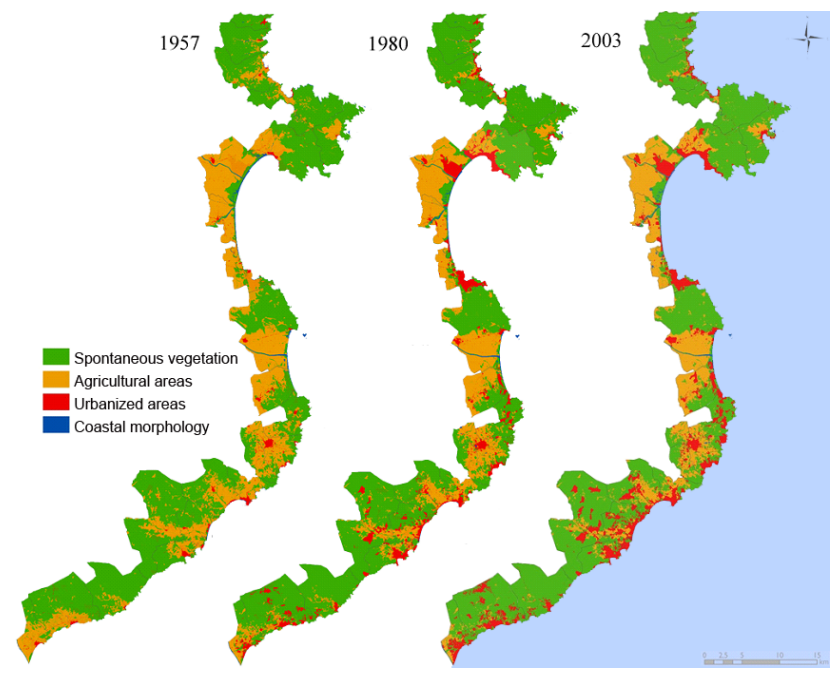

Fig. 2. Main land use changes in the Costa Brava between 1957 and 2003 (source: Martí, 2005).

The aim of this paper is to investigate social perceptions and assessments of flooding using three different participatory methods: surveys, interviews, and Focus Groups. More specifically we want to explore the differences between individual and collective assessments of floods and of flood management, and between public, private, and civic interests. Our study area is formed by three municipalities of the Costa Brava, in the Northeastern tip of the Iberian Peninsula: Calonge, Tossa de Mar and Torroella de Montgrí (see Fig. 1). These municipalities share similar social and spatial patterns, marked by tourism and intense urban growth, and have suffered in recent decades flooding problems, either by overflow from rivers and smaller streams or by storm surges driven by easterly winds.

The paper is organised as follows: after this introduction in section two we present our study area. In section three we develop our methods for the collection of data on flood perception and assessment. Section four is dedicated to data analysis and discussion of results while section five offers some conclusions regarding the feasibility of the different participatory methods in our study cases.

\section{Geographical context: the Costa Brava}

The Costa Brava stretches along the 22 coastal municipalities of the Girona province and is located between the SpanishFrench border (Portbou), in the north, and the Tordera river (Blanes), in the south (see Fig. 1). The rivers Muga, Fluvià and Ter are the main fluvial courses of this area. Figure 2 shows the intense process of urbanization observed in the municipalities of the Costa Brava between 1957 and 2003 due to the growth of the tourist and the residential establishments. In the opposite direction, agricultural areas have 
Table 1. Population change and tourist accommodation capacity in studied municipalities (Source: Institut d'Estadística de Catalunya, www.idescat.cat).

\begin{tabular}{lccccc}
\hline Municipalities & \multicolumn{4}{c}{ Permanent population } & Tourist accommodation capacity \\
& 1955 & 1981 & 2003 & 2009 & in hotels and campings (2009) \\
\hline Calonge & 2851 & 4362 & 8282 & 10637 & 8438 \\
Torroella de Montgrí & 4369 & 5599 & 9393 & 11598 & 14530 \\
Tossa de Mar & 1405 & 2969 & 4786 & 5948 & 14215 \\
TOTALS & 8625 & 12930 & 22461 & 28183 & 37183 \\
\hline
\end{tabular}

suffered an important decline. The three municipalities studied are clear examples of these trends.

The Costa Brava, as its name indicates, refers to a rough territory, where cliffs alternate with small bays and, more occasionally with larger river plains. This component is an aspect to take into account in the phenomenon of flooding in the coastal municipalities. The proximity of the hills of the Catalan Coastal Rangel and the foothills of the Pyrenees to the sea facilitate the existence of small basins with steep slopes. This exacerbates the effects of flooding by streams which usually run dry during much of the year.

Once responsible for large floods, these rivers have been subject to intensive regulation with the result that the hazard has moved to coastal streams of torrential regimes generating dangerous flash floods (Saurí and Ribas, 2006; Saurí et al., 2001). The main population centres are located generally on the beach front (the lower and shallower areas and therefore those more susceptible to the effects of inundation) but also and more recently, take the form of housing developments of very different types (from houses to townhouses) that escalate the slopes of the mountain and invade small inland plains. The urban area of the Costa Brava had increased substantially over the past 50 years, expanding from 1139.5 ha. in 1957 (1.7\% of the total area) to $8765.1 \mathrm{ha}$. in 2003 (13.2\% of the total area). In turn, population grew from 70948 inhabitants in 1960 to 249852 in 2009. Tourism remains the most important economic activity, with some 160000 beds in hotels, apartments and campsites, and more than 17 million overnight stays in 2008 (IDESCAT, 2008). In Table 1 we present data regarding population change in the three municipalities studied since the mid 1950s. Between 1955 and 2009 the permanent population of these municipalities has more than tripled. In addition to this growth we must consider the expansion of tourist accommodation. In 2009 the tourist accommodation in these three towns amounted to 37183 beds including hotels and campings. This figure does not include apartments and houses used for tourist purposes.

Floods in this area tend to occur after torrential rains (up to $200 \mathrm{~mm}$ of precipitation in $24 \mathrm{~h}$ ) typical of Mediterranean regimes in the fall (Llasat et al., 2009). Flood control works have thus far succeeded in containing the large floods of the past originating in the Muga, Fluvià and Ter river basins. As said before, flooding problems in these rives have mutated into flooding caused by coastal ephemeral streams. Once these streams are supposedly brought under control by a new generation of hydraulic works (including the conversion of natural streams into underground artificial channels), floods, however, still reappear this time under the form of diffuse flows and inundate large parts of the coastal settlements to a greater extent as a result of soil sealing caused by urbanization.

That said, it is also true that floods cause very few human losses (and a substantial part of them attributable to imprudent behaviour: i.e. attempt to cross a flooding stream with a four wheel drive vehicle). Economic losses are large, especially in the public sector, but Spain has developed a comprehensive system of flood insurance for individuals and local administrations that ensures a certain recovery of these losses. In terms of greater exposure to floods, we must highlight the contribution of both increasing human occupation of flood areas and of significant changes in the hydrological regime of rivers and smaller streams in the sense of increasing flood peaks and reducing concentration times. All these conditions can be found in the three municipalities of our study. Among the worst flood episodes of recent years two in particular must be mentioned: the episode of October 1994 in Torroella de Montgrí-l'Estartit $(217.8 \mathrm{~mm}$ in $24 \mathrm{~h}$ and more than 6 million euro in economic losses) and the episode of October 2005 in Calonge (254.5 mm in 24 h, 20 million euro in economic losses).

\section{Materials and methods}

Our data on flood perception and assessment in the municipalities selected for analysis has been obtained from three different sources: (a) surveys of temporal and permanent residents in flood prone areas, (b) in-depth interviews with the mayors and/or local technical experts of each municipality, and (c) Focus Groups with representatives of the local public, private and civic spheres.

A total of 285 surveys were conducted (95 in each municipality) in May and June 2008. All respondents resided, either temporarily or permanently, in the area with a flood return period of 500 years, although not all had been affected 
Table 2. Range of different flood management options. Residents (respect to Figs. 7 until 11).

\begin{tabular}{cl}
\hline A & Stream channelization \\
B & Stream diversion \\
C & Dam or reservoir \\
D & Dual network of rainwater/wastewater \\
E & Cleaning and maintenance of the fluvial bed \\
F & Creating regulated flood spaces (swaps, lagoons, etc.) \\
G & Forbidding development in flood areas \\
H & Arranging adequate warning and evacuation systems (emergency planning ) \\
I & Arranging a right compensation system \\
J & Others (specify) \\
NA & No answer \\
\hline
\end{tabular}

by the episodes that occurred in recent years. Surveys were administered during Friday afternoons and Saturday, when most residents could be usually found at their homes. The selection of the spatial distribution was carried out proportionally to the number of persons present in the various urban areas susceptible to flooding. The survey consisted of a semiopen questionnaire of 23 questions divided into three sections (background personal data, experience with the risk of flooding, and assessment of existing management measures and preferences on which should be promoted) (Table 2).

In depth interviews with mayors and the environmental city managers (completed in the fall of 2008 and spring of 2009) consisted of 30 questions divided in four sections: assessment of the flood hazard in the municipality; physical characteristics and exposure; vulnerability, and assessment of adaptation options, both existing and to be implemented (Table 3). Finally, Focus Groups (one for each municipality, 3 in total) included 26 representatives of five social groups (local administration, neighbourhood community groups, economic sector, scientists, and environmental NGOs). These sessions, conducted in different time periods of 2009, were structured following an open outline of four major issues: an assessment of the flood problem in the municipality; the management options pursued and the management options desired to curb flood impacts (Table 4); the causes of the flood problem (Table 5), and finally the role of citizens in flood management. Each session lasted for about three hours and was chaired by a senior member of the research team.

\section{Results}

In this section we will present the results of our research. Most of these results will be introduced aggregately for the three municipalities since we are especially interested in trends of the area as a whole. First we will comment results regarding the perception of vulnerability to floods by residents, local mayors and local managers, and participants
Table 3. Management options cited by mayors and local managers (respect to Fig. 12).

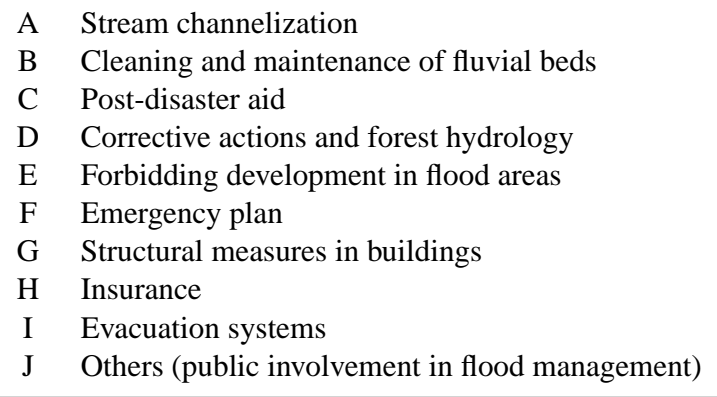

in Focus Group sessions. Second, we will move to the issue of flood management and its perception by residents, local mayors and local managers, and participants in Focus Group sessions. Third, we will move to perceived causal factors and to the issue of public participation as recorded in the Focus Group sessions.

\subsection{Perception of vulnerability to flooding}

Beginning with the survey of residents in flood prone land and as expected the condition of having been affected or not by a flood event determines the perception that residents have about their vulnerability to flooding (Fig. 3).

Affected residents, whether permanent or temporary, felt highly vulnerable to floods ( $71 \%$ and $82 \%$ respectively). However, this proportion fell dramatically (to $37 \%$ ) in the case of non-affected residents.

The presence or absence of individuals that, because of their age, may have known about past flooding in the region also influences the attitude of the community to these risks. In this study, the average age of the population of the three municipalities surveyed was 52.87 years. The affected temporary residents ranked first in the perception of vulnerability 
Table 4. Management options cited by social sectors in Focus Group sessions (respect to Fig. 13).

\begin{tabular}{llll}
\hline A & Widen stream beds & K & Cleaning and maintenance of fluvial beds \\
B & Educational campaigns & L & Flood management in real time \\
C & Flood retention tanks in houses & M & Better urban planning \\
D & Construction of flood retention dams & N & High capacity sewers \\
E & Construction of rain water collectors & O & Re-align stream course near the sea \\
F & Coordination among different public bodies & P & Emergency plans \\
G & Flood retention tanks & Q & Protection of flood prone land \\
H & Flood retention natural areas & R & A more active role by university experts \\
I & Compensation Systems for losses & S & Improve drainages \\
J & Avoid modification of soils & & \\
\hline
\end{tabular}

Table 5. Human causes of the flood problem. Social sectors in Focus Group sessions.

\begin{tabular}{lr}
\hline Human causes & $\%$ \\
\hline Urban growth in flood prone land & 75.5 \\
Insufficient urban drainage & 21.1 \\
Lack of sound technical criteria in flood control works & 21.1 \\
Poorly designed flood control works & 21.1 \\
Insufficient municipal power & 6.7 \\
Insufficient supramunicipal power & 3.3 \\
Coordination between levels of government & 10.0 \\
Lack of stream cleaning and maintenance & 36.7 \\
Insufficient capacity of the final section of the river & 2.2 \\
Artificialization of streams & 27.7 \\
Lack of management tools in real time & 12.2 \\
Unfamiliarity with the area & 5.5 \\
\hline
\end{tabular}

Table 6. Average age. Residents.

\begin{tabular}{lcccc}
\hline Residents & Torroella & Tossa & Calonge & Average \\
\hline Per. affect. & 49.83 & 48.00 & 53.65 & 50.49 \\
Per. unaff. & 47.41 & 45.58 & 57.44 & 50.14 \\
Temp. affect. & 61.63 & 59.50 & 60.21 & 60.45 \\
Temp. unaff. & 47.37 & 49.94 & 53.88 & 50.40 \\
\hline
\end{tabular}

(Fig. 3). Additionally, they were also the group with a highest average age (60.45 years) (Table 6).

For the local governments in two of the three municipalities studied, the perception of vulnerability to floods ranked high (average of $75 \%$ ) whereas in the third (Calonge) this figure was lower $(50 \%)$ probably because of the recent channelization of the stream that caused the main problems in the town (Fig. 4).

The highest score regarding vulnerability, however, was attained in the Focus Groups sessions (Fig. 5). 96.67\% of the stakeholders considered that their municipalities were vul-

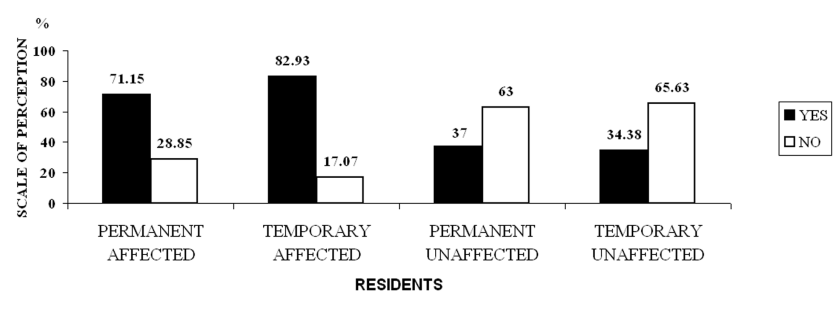

Fig. 3. Perception of vulnerability to flooding. Residents.

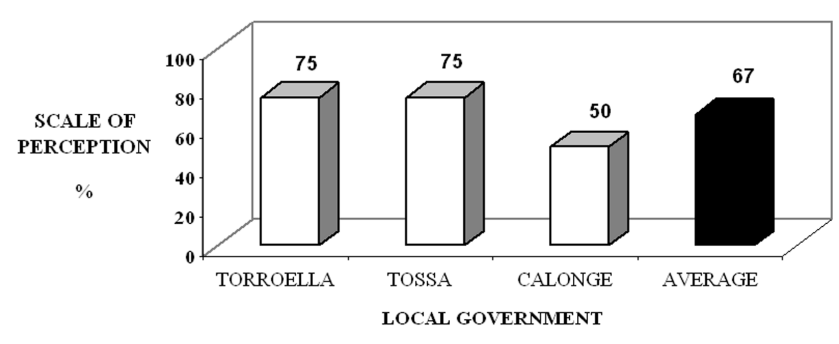

Fig. 4. Perception of vulnerability to flooding. Local governments.

nerable to floods. This opinion was shared unanimously by all represented sectors with the exception of NGOs. This may be probably explained by the fact that NGOs do not necessarily consider floods as negative phenomena but acknowledge the importance of these events in environmental terms.

\subsection{Perception of flood management measures}

Respondents to the survey manifested a unanimous agreement in that existing management measures were insufficient to mitigate or reduce vulnerability to flooding. In the analysis of survey results, affected residents and particularly affected temporal residents expressed the greatest disapproval of current flood management practices (Fig. 6).

Among the not affected residents, those who disapproved flood management practices were dominant. However, the number of respondents in this category that considered management "good" achieved a significant $25 \%$ among 


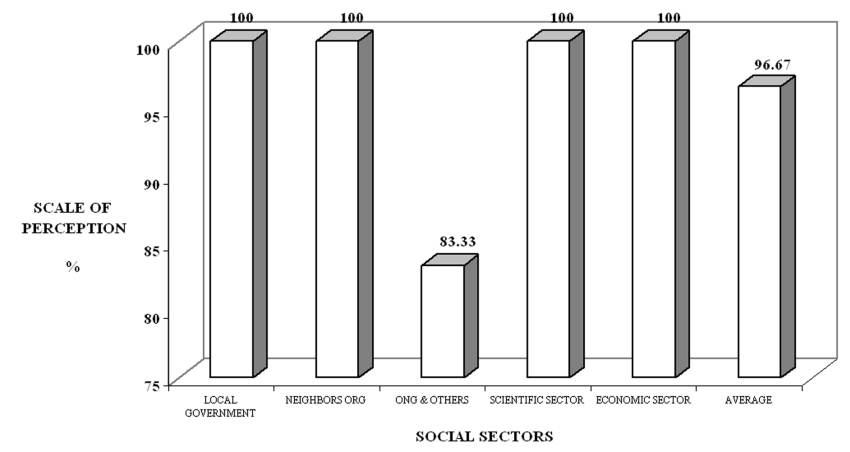

Fig. 5. Perception of vulnerability to flooding. Social sectors of Focus Group sessions.
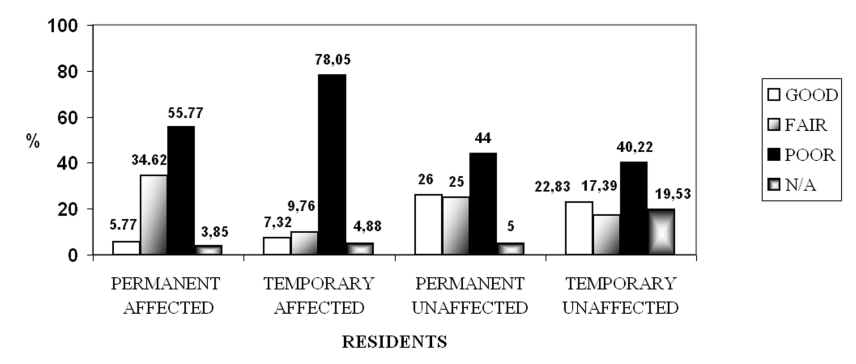

Fig. 6. Assessment of flood management practices. Residents.

permanent residents and $17.35 \%$ among temporal residents. The category of non affected temporal residents also registered the highest proportion (20\%) of non responses.

Three of the four groups of residents surveyed (Figs. 7-11) but especially the group of permanent residents, regardless of whether they had been affected by flooding or not, selected two main flood management options: the cleaning of river beds and the channelization of rivers and streams. Only in the group of temporary residents unaffected by flooding priorities followed a different course and showed a wider range of preferences. From most preferred to less preferred were the "prohibition of the development in flood areas" (35.9\%), the "clearing of watercourses" (32.6\%), the "channelling of rivers" $(28.5 \%)$ and "emergency plans" $(27.2 \%)$. It is particularly interesting to note how temporary residents, regardless of whether they had been affected or not, were those displaying a higher degree of diversification in their preferences as opposed to more polarized preferences found among permanent residents. This could be explained by the differences between the two groups regarding the degree of belonging or attachment to a particular area. Thus, the closeness to the area and the greater experience with floods may facilitate the selection of options (i.e. hydraulic works) that are seen as real "solutions" to the flood problem. However, on the other hand having a more distant and external view of the problem, may help in taking a more holistic and objective view on the management of this risk, thus widening the range of choice of possible management options beyond the usual option of modifying streams.

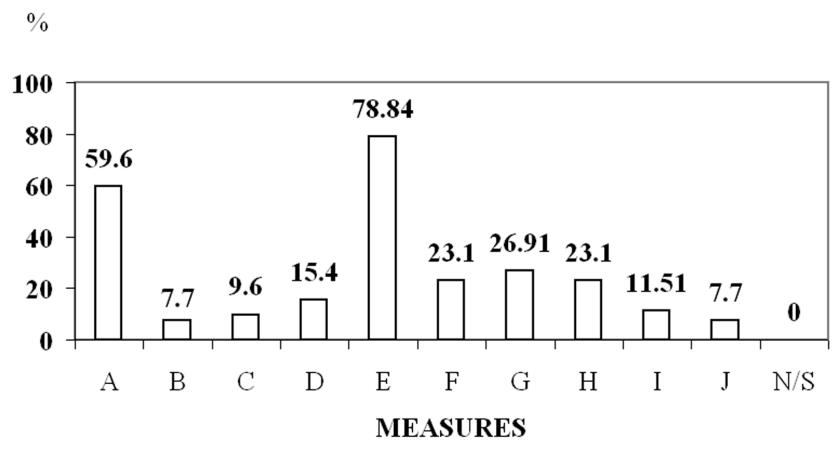

Fig. 7. Preferences for different management measures. Affected permanent residents.

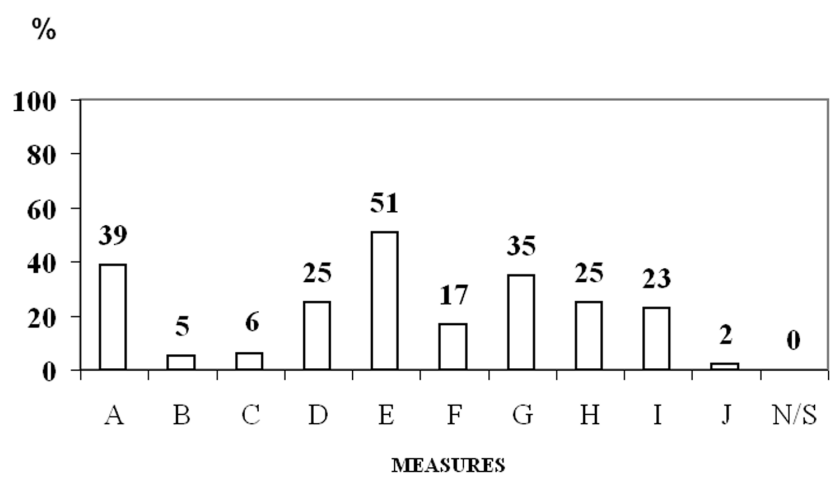

Fig. 8. Preferences for different management measures. Unaffected permanent residents.

It is interesting to note that in interviews with municipal officials; we found out that local managers largely prefer hydraulic works (mostly river channelization) as the more suitable alternative to reduce exposure against flooding (see Fig. 12). However, it is also true that with regard to previous studies in the same areas carried out in the mid 1990s (Roset et al., 1999; Saurí et al., 2001) these local managers also show a certain change towards "greener" discourses in flood management. At any rate, the high adhesion to the construction of flood defences, that is an option that implies the modification of natural processes but not of human behaviour with respect to floods, contrasts with options such as "Prohibit development in flood areas" much less preferred.

All the participants in the Focus Groups considered current flood management practices as either insufficient ( 60 per cent of the social groups participating) or even non-existing (40 per cent) (Table 4 and Fig. 13).

For example in Calonge these opinions were especially surprising given that in the moment of conducting the present research, the channelization of the riera (the main stream), presumably a very important action for curbing future flood losses, was under way. In sum, floods were perceived as very important and current management options, even flood control works, did not appear as adequate. 
$\%$

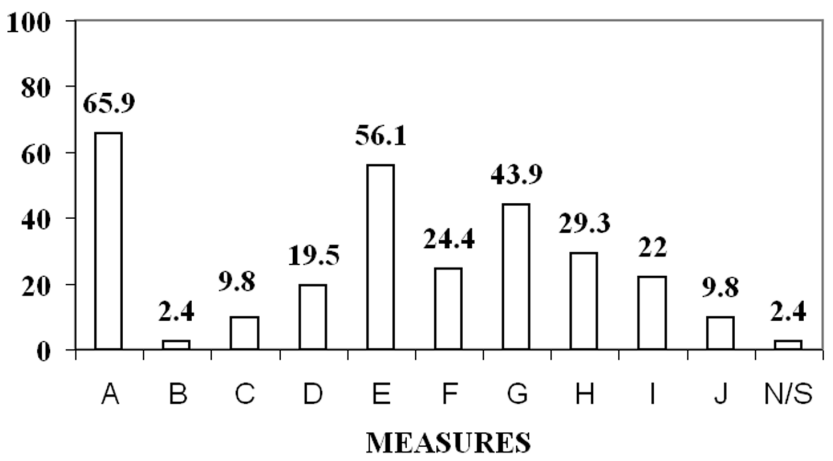

Fig. 9. Preferences for different management measures. Affected temporal residents.

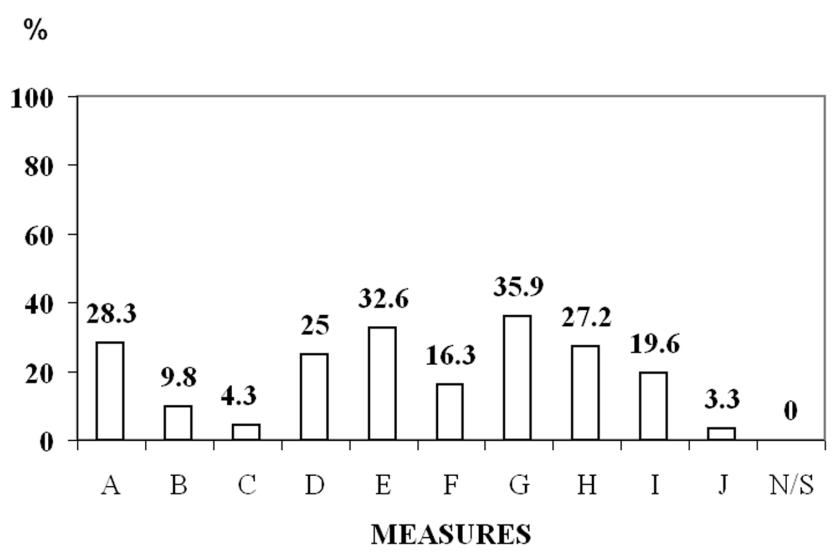

Fig. 10. Preferences for different management measures. Unaffected temporal residents.

For its part, the social sectors identified 19 specific actions that could be implemented to reduce vulnerability to flooding. Within this range, seven options appear to be especially relevant, and among them two in particular: urban planning and the implementation of emergency plans. In the Focus Group sessions, structural (i.e. engineering) solutions to the flood problem were contested with the argument that they tended to create more problems than solutions.

\subsection{Perception of human causes in flood episodes (Focus Group sessions)}

Participants in the Focus Group sessions were also asked to identify the human causes that contributed to increase vulnerability to floods. A total of twelve causes were identified half of which were highly shared by participants whereas the other half were raised by a smaller number of participants (see Table 5).

The most important cause of increasing vulnerability to flooding as reported by participants was the urbanization process in flood prone land. Other important causes reported

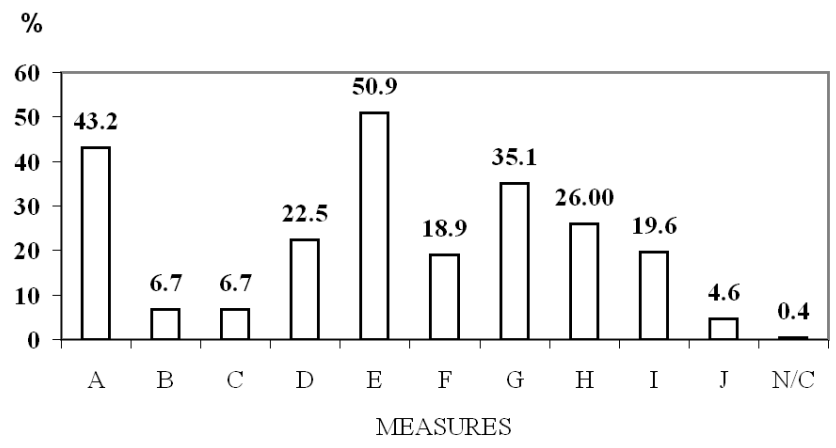

Fig. 11. Preferences for different management measures. All residents.

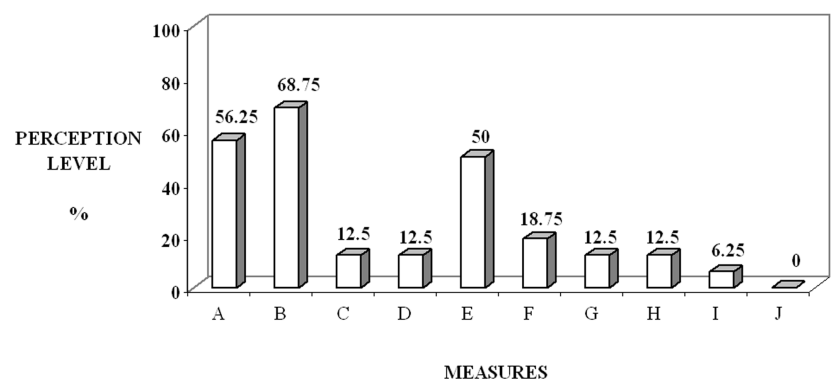

Fig. 12. Preferences for flood management options. Mayors and local managers.

were the lack of cleaning and maintenance of watercourses, and poorly designed infrastructures. From the discussions originating in the sessions, participants also felt that more non-structural (i.e. non technological) measures needed a mnore careful assessment.

\subsection{Public participation in flood management (Focus Group sessions)}

As to the issue of participation, all Focus Groups unanimously agreed that citizens were not involved in decisions regarding flood management. Reasons argued to defend this view were, on the one hand, the lack of motivation and interest by citizens, and, on the other, a similar disinterest by local administrations. But it was also added that his situation would probably change in the coming years with the implementation of the EU Flood Directive. For participants in the Focus Groups sessions, citizens and citizen organizations needed to have a more active role in specific actions related to the management of the flood risk (see Fig. 14). In the discussions, citizen participation was considered relevant and necessary, although focus group members also remarked that, thus far and in general, participation did not appear to be able to go beyond the level of action-reaction, and was seldom pro-active. That is, organized citizens would participate at the request of local governments but not under their own initiative. Participation would also occur in cases where 


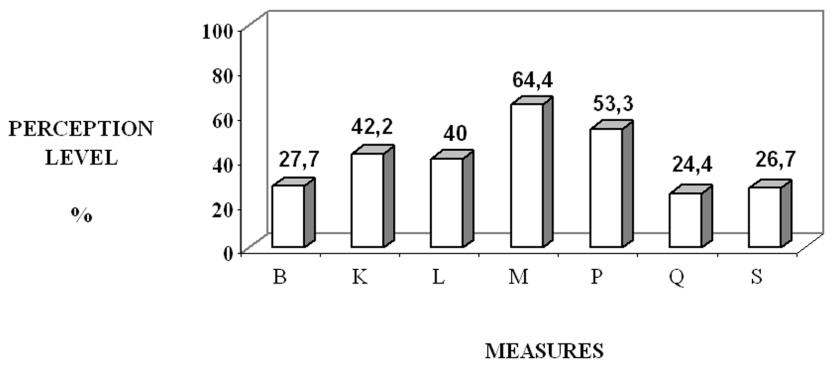

Fig. 13. Preferences for flood management measures. Social sectors in focus group sessions.

citizens felt directly affected by an adverse phenomenon such as a flood or if these citizens perceived that certain public actions could increase their vulnerability to flooding.

\section{Discussion and main findings}

In this section we will summarize the main findings of our research:

First, there was no agreement among the various sectors studied on the nature of vulnerability to floods in the three areas examined. In the case of ordinary residents, their perception was directly linked to the experience with the risk of flooding; in other words and as it is well known, the perception of vulnerability increased with experience. Local governments recognized the existence and importance of the flood risk. However, this importance changed according to the reality of each municipality and to the political priorities set in each case. In contrast, all social agents participating in the Focus Group sessions considered the risk of flooding tangible and important.

Second, in identifying the human causes that contribute to increasing levels of exposure to the risk of flooding, the process of urbanization in flood zones clearly stood as the main problem for participants in the Focus Group sessions. It is likely that the intense processes of land use change experienced by the Costa Brava during the last 50 years and their perceived beneficial and negative effects influenced, in turn, the perception of this issue. Overall, however, local societies have not opposed such changes in the past nor have they been able to or sought to participate in the management of these changes. New governance forms such as those introduced by the EU Floods Directive and its consolidated policies and guidelines, as well as specific regulations on planning and public participation in flood management, will surely change this state of affairs. Participation in flood management, however, faces the challenge of moving from being reactive to being more proactive. Coming from a culture of confrontation and dissent, many social groups, and especially many environmental NGOs, have now the opportunity of becoming proponents of new options for sound flood management policies.

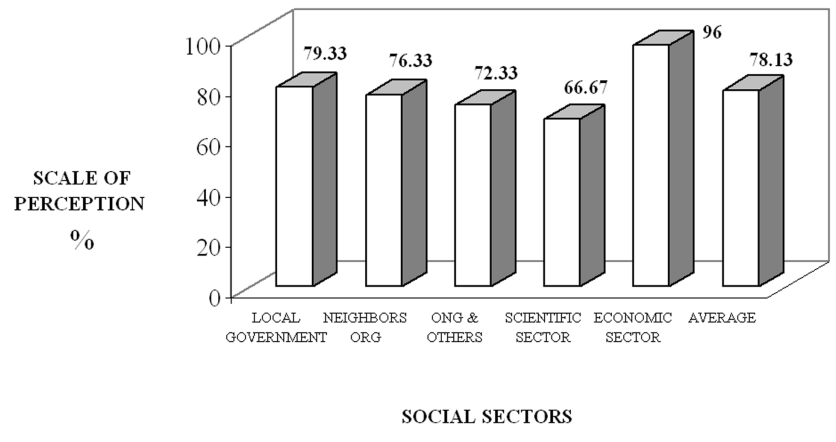

Fig. 14. Relevance of public involvement in flood management. Social sectors in Focus Group sessions.

Third, regarding the perception of current flood management, surveys, interviews and Focus Group sessions all showed the need to improve the performance of measures addressed to curb flood losses. Affected residents and participants in Focus Group sessions registered the highest negative assessment of flood management measures implemented whereas non affected residents tended to show a more balanced view of flood management (the good, fair, and poor categories have similar values). On the other hand those directly responsible for implementing flood management actions argued that they had undertaken significant actions to mitigate the problem caused by flooding in their municipalities, mainly through hydraulic works. Beyond this option, which is funded by regional and national organizations, the relevance given by the local administration to the flood risk is critical to ensure the application of other management measures. Many times the need of improving flood policy is acknowledged but other political priorities preclude the implementation of these improvements.

Fourth, with regard to what kind of actions should be implemented in the study area, residents, local government officials, and participants in the Focus Group sessions appeared inclined to agree on a combination of actions that included structural (i.e. flood control engineering works) with nonstructural (i.e. land use planning) options. The most cited actions were the cleaning and maintenance of river beds, stream channelization and the prohibition of urban development in flood-prone areas. As to more specific preferences, only participants in Focus Group sessions considered non structural options as key elements in flood management. They acknowledged the importance of hydraulic works but warned that this option should not have preference over other options and, even more so, when total security could not be guaranteed and environmental impacts could be significant. From the Focus Group sessions emerged a framework for flood management that gave priority to options that did not produce high environmental impacts, helped to reduce future vulnerabilities without having to resort to the uncertain performance of technological fixes in case of large events, and called for 
a more active role of citizens. Hence, the emphasis given to urban planning, the development of operational emergency plans, the tasks of cleaning and maintenance of watercourses, and, more generally, to flood management based on real and timely information.

\section{Conclusions}

Floods continue to be an important problem for coastal Mediterranean areas, and a problem exacerbated by intense urban growth in the last decades. Although large floods in river basins appear more and more unlikely, flash floods by ephemeral streams and, more recently, floods caused by insufficient drainage are on the rise. For a variety of economic, social, and environmental reasons, new flood policies such as those stemming from the EU Floods Directive of 2007 appear to be less inclined towards structural (i.e. hydraulic) solutions and more sympathetic to non structural (i.e land use regulations) solutions. This trend is part of a larger shift in environmental governance and especially in risk governance by which some of the responsibilities in management (especially the responsibility of assuming the economic costs of some management actions) are returned to individual citizens. This in turn requires major changes in the dominant social perception and attitudes towards natural hazards so that processes of social learning can be put into motion. Hence, the need to change individual perceptions through active channels of public participation so that social learning increases and more sustainable policies may follow.

In this paper we have attempted to show how the level of social involvement that each citizen has in relation to the place he or she lives has a direct impact on their perception and assessment of the various problems existing and of the best risk management methods to cope with risk. If the level of individual involvement is low, then solutions that do not impose duties, obligations and individual responsibilities are preferred. At the opposite end the higher the involvement the more likely are individual management actions with regard to floods. This is why processes of social learning through public participation attain such relevance in risk management and, more generally in environmental management. If citizens are given the change of participate actively in the development of strategies against flooding this may result in the seeking of agreements that put the common good above individual interests. Only in this way we may implement public policies that: (a) involve real changes in human, social and economic behaviour in relation to the occupation and alteration of flood areas, (b) facilitate the development of genuine and effective strategies to mitigate flood risk and (c) facilitate the achievement of the objectives of EU Floods Directive.

Acknowledgements. This research has been possible thanks to the Spanish CICYT under the VULNEMED project (SEJ200615153-C03-01/GEOG and SEJ2006-15153-C03-02/GEOG). We would like to thank all participants in the surveys, interviews and
Focus Groups sessions in Calonge, Torroella de Montgrí, and Tossa de Mar. We would like to thank also Maria Carmen Llasat for encouraging us to submit our work for publication, and the editor and reviewers of this journal for their helpful comments and criticisms.

Edited by: M.-C. Llasat

Reviewed by: two anonymous referees

\section{References}

Adams, J.: Risk, University College London Press, London, 1995. Australia and New Zealand Standard Association: The Australia/New Zealand Risk Management Standards, Australia and New Zealand Standards, 4360, Sydney and Auckland, 1995.

Barredo, J. I.: Normalised flood losses in Europe: 1970-2006, Nat. Hazards Earth Syst. Sci., 9, 97-104, doi:10.5194/nhess-997-2009, 2009.

Brilly, M. and Polic, M.: Public perception of flood risks, flood forecasting and mitigation, Nat. Hazards Earth Syst. Sci., 5, 345355, doi:10.5194/nhess-5-345-2005, 2005.

Burton, I., Kates, R. W., and White, G. F.: The Environment as Hazard, Oxford University Press (2nd Edition), 1993.

Calvo García-Tornel, F. and Granell, M. C.: Valoración social del riesgo por inundación en el litoral meridional de la región de Murcia, Scripta Nova, XIII, 295, 2009.

Edelenbos, J. and Klijn, E.-H.: Managing stakeholder involvement in decision making: A comparative analysis of six interactive processes in the Netherlands, J. Public Administration Research and Theory, 16, 417-446, July 2006.

European Environment Agency: Environmental Signals 2002, Environmental assessement report, 9, 2002.

Gersonius, B., Zevenbergen, C., and van Herk, S.: Managing flood risk in the urban environment: linking spatial planning, risk assessment, communication and policy. Adaptive and Integrated Water Management, Springer Berlin Heidelberg, 263-275, 2008.

Goulbdy, B. and Samuels, P.: Language of risk-project definitions, Flood site Project Report T32-04-01, March 2005.

Guzzetti, F., Stark, C. P., and Salvati, P.: Evaluation of flood and landslide risk to the population of Italy, Environ. Manage., 36(1), 15-36, 2005.

Huisman, P.: La gestió de les inundacions als Països Baixos, Documents d'Anàlisis Geogràfica, 31, 57-31, 1997.

Kates, R. W.: Hazard and Choice Percpetion in Floodplain Management. University of Chicago, Geography Department Reseach Paper, 78, 1962.

Lacey, C. and Longman, D.: The Press as Public Educator: Cultures of Understanding, Cultures of Ignorance, University of Luton Press, Luton, 1997.

Llasat, M. C., Llasat-Botija, M., and López, L.: A press database on natural risks and its application in the study of floods in Northeastern Spain, Nat. Hazards Earth Syst. Sci., 9, 2049-2061, doi:10.5194/nhess-9-2049-2009, 2009.

Martí, C.: La transformació del paisatge litoral de la Costa Brava: Anàlisi de l'evolució (1956-2003), diagnosi de l'estat actual i prognosi de futur, $\mathrm{PhD}$ thesis, University of Girona, Girona, 2005.

Meyer, V., Scheuer, S., and Haase, D.: A multicriteria approach for flood risk mapping exemplified at the Mudle river, Germany, Nat. 
Hazards, 48, 17-39, 2009.

Olcina, J.: Riesgos de inundaciones y ordenación del territorio en España, Instituto Euromediterráneo del Agua, Murcia, 2007.

Pearce, L.: Disaster Management and Community Planning, and Public Participation: How to Achieve Sustainable Hazard Mitigation, Nat. Hazards, 28, 211-228, 2003.

Pearce, L.: The value of public participation during a hazard, impact, risk and vulnerability (HIVR) analysis, Mitigation and Adaptation Strategies for Global Change, 10, 411-441, 2005.

Plapp, T.: Perception and Evaluation of Natural Risks. Interim report on first results of a survey in six districts in Germany. Risk Research and Insurance Management, Working Paper No. 1, November 2001.

Platt, R. H.: Disaster and democracy: The politics of extreme natural events, Island Press, Washington, D.C., 1999.

Renn, O.: Three decades of risk research: accomplishment and the new challenges, J. Risk Res., 1(1), 49-71, 1998.
Rubin, C.: Recovery from disaster, in: Emergency Management: Principles and Practices for Local Government, edited by: Drabek, T. E. and Hoetmer, G. J., International City Washington, D.C., 224-261, 1991.

Saurí, D. and Ribas, A.: Las inundaciones en Cataluña. Un estado de la cuestión para la década de 1990 y algunas reflexiones para el futuro, in: Riesgo de inundaciones en el Mediterráneo occidental, edited by: Chastagnaret, G. and Gil Olcina, A., Casa de Velázquez, Madrid, 273-294, 2006.

Saurí, D., Roset, D., Ribas, A., and Pujol, P.: The 'escalator effect' in flood policy: the case of the Costa Brava, Catalonia, Spain, Applied Geography, 21, 127-143, 2001.

White, G.: Human Adjustments to Floods: A Geographical Approach to the Flood Problem in the United States. Doctoral Dissertation, Department of Geography, University of Chicago, 1995. 